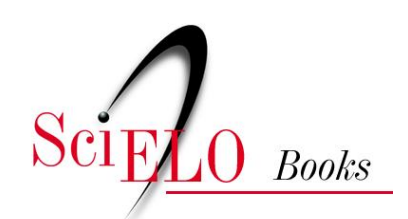

\title{
13. Técnicas moleculares aplicadas à sistemática e ao controle vetorial
}

\author{
Márcio Galvão Pavan \\ Fernando Araujo Monteiro
}

\section{SciELO Books / SciELO Livros / SciELO Libros}

PAVAN, MG., and MONTEIRO, FA. Técnicas moleculares aplicadas à sistemática e ao controle vetorial. In: GALVÃO, C., org. Vetores da doença de chagas no Brasil [online]. Curitiba: Sociedade Brasileira de Zoologia, 2014, pp. 241-260. Zoologia: guias e manuais de identificação series. ISBN 978-85-98203-09-6. Available from SciELO Books $<$ http://books.scielo.org $>$.

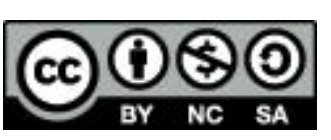

All the contents of this chapter, except where otherwise noted, is licensed under a Creative Commons Attribution-Non Commercial-ShareAlike 3.0 Unported.

Todo o conteúdo deste capítulo, exceto quando houver ressalva, é publicado sob a licença Creative Commons Atribuição Uso Não Comercial - Partilha nos Mesmos Termos 3.0 Não adaptada.

Todo el contenido de este capítulo, excepto donde se indique lo contrario, está bajo licencia de la licencia Creative Commons Reconocimento-NoComercial-CompartirIgual 3.0 Unported. 


\title{
13. Técnicas moleculares aplicadas à sistemática e ao controle vetorial
}

\author{
(Márcio Galvão Pavan \& Fernando Araujo Monteiro)
}

"Nada em Biologia faz sentido, exceto à luz da evolução"

(T. Dobzhansky)

\section{Teoria Evolucionista de Darwin e a Genética Mendeliana}

Até a metade do século XIX, basicamente duas correntes opostas de pensamento permeavam a comunidade científica: (1) o essencialismo platônico, defendido pela igreja, e (2) a ideia de que as espécies não eram imutáveis e de fato evoluíam ao longo do tempo. Esta última claramente ia de encontro aos tradicionais paradigmas religiosos.

O naturalista inglês Charles Darwin (1809-1882), ao partir de Plymouth na Inglaterra em 1831 a bordo do navio HMS Beagle para uma viagem de quatro anos e nove meses ao redor do mundo, não fazia ideia de que as observações que faria (e deduções decorrentes) viriam a revolucionar o entendimento sobre a origem das espécies e da diversidade biológica. Suas anotações referentes à morfologia, ecologia e comportamento sobre organismos presentes nas regiões estudadas no hemisfério sul, além das informações sobre os fósseis encontrados, serviriam de base para a elaboração da teoria evolucionista.

As principais ideias e conceitos que caracterizam a teoria evolucionista de Darwin somente se tornaram maduros quando foram associados às informações oriundas dos estudos demográficos de Thomas Malthus (1766-1834). Darwin apenas ganhou confiança suficiente para publicá-los no livro "Origem das Espécies" (1859), um dos livros mais vendidos da história, ao tomar conhecimento das conclusões descritas por Alfred Russel Wallace (1823-1913). As observações feitas por este naturalista galês sobre a distribuição geográfica e aspectos da geologia de organismos da Malásia, Indonésia e Brasil, o levaram a atingir as mesmas conclusões que Darwin sobre a competição pelos recursos naturais disponíveis. Wallace ainda contribuiu para a elaboração do conceito de ancestralidade comum ao sugerir a existência de populações ancestrais que, em determinadas circunstâncias, teriam se separado e se adaptado a diferentes ambientes, dando origem a novas espécies.

Com o objetivo de explicar a variabilidade e a adaptabilidade das espécies, Darwin criou o conceito de "seleção natural", com base nas observações sobre demografia, postulando que os organismos competiriam por recursos naturais limitados levando à sobrevivência (seleção) dos mais aptos. A variabilidade natural dos organismos seria decorrente de modificações que surgiriam 
ao acaso e que seriam selecionadas com o passar do tempo. Aqueles organismos que viessem a sofrer modificações fenotípicas favoráveis à sua adaptação ao ambiente passariam a ter mais chances de sobreviver e de reproduzir. Se estas características novas fossem hereditárias, este fenótipo tornar-se-ia cada vez mais comum nas gerações subsequentes, levando à modificação da morfologia (evolução) desta espécie.

A teoria de evolução por seleção natural proposta por Darwin e Wallace veio a explicar elegante e convincentemente como as espécies se adaptam ao meio em que vivem. Embora robusta e inovadora, a teoria apresentava dois pontos fracos: (1) não explicava o mecanismo de transmissão da variabilidade de uma geração para a outra, e (2) propunha que a herdabilidade das características ancestrais era baixa e, por isso, de relevância secundária.

Sete anos após a publicação da obra de Darwin, Gregor Mendel (1822-1884), um monge austríaco com interesse em botânica, fazia descobertas inovadoras. Mendel observou que certas características da geração parental eram quase todas mantidas na geração seguinte. Em experimentos de cruzamento usando ervilhas como modelo, ele estabeleceu três "leis" fundamentais sobre a hereditariedade dos caracteres: (1) a Lei da Pureza dos Gametas, cuja ideia principal é que cada par de alelos determina um caráter; durante a formação dos gametas, os pares são separados, de maneira que cada locus do zigoto seja formado com um alelo materno e outro paterno; (2) a Lei de Independência dos Caracteres, na qual Mendel afirma que cada característica fenotípica é herdada independentemente; e (3) a Lei de Dominância, segundo a qual a presença de alelos dominantes, seja em homozigose ou heterozigose, leva à produção do mesmo fenótipo.

Os experimentos realizados por Mendel foram fundamentais para o avanço do conhecimento sobre o papel dos genes na herança dos caracteres fenotípicos. Ainda que seus experimentos demonstrassem corretamente que os caracteres ancestrais eram mantidos na geração subsequente, Mendel era criacionista e não acreditava que as espécies podiam evoluir.

As ideias inovadoras e revolucionárias de Charles Darwin (1859) e Gregor Mendel (1865) quebraram o paradigma vigente e estabeleceram uma nova forma de explicar a variabilidade vista na natureza. Esta mudança teve reflexo imediato na maneira como os naturalistas agrupavam ou classificavam os organismos. A partir desse momento, o parentesco evolutivo passou a ser levado em consideração.

No fim da década de 1930, diversos pesquisadores (Thomas Morgan, Theodosius Dobzhansky, Ernst Mayr, Julian Huxley, entre outros) formularam a síntese evolutiva moderna, ou Neodarwinismo. Esta síntese é uma fusão da teoria da seleção natural darwiniana, herança mendeliana e genética de populações, além de conter informações de outras áreas do saber, como a zoologia e paleontologia. O Neodarwinismo procurou explicar como as espécies evoluem e dão origem a novas espécies.

Oito anos após a divulgação da síntese evolutiva moderna, esforços individuais como os do entomólogo alemão Willi Hennig (1950) foram fundamentais para a definição de métodos objetivos para estudos de reconstrução filogenética com base em caracteres morfológicos (marcadores moleculares ainda não existiam). Segundo Hennig, todos os organismos estão relacionados (em maior ou menor grau), já que todos compartilham a mesma origem e estão conectados por relações de ancestralidade e descendência. O ponto fundamental da metodologia analítica por ele proposta foi o conceito de parcimônia. Para Hennig, a evolução é econômica. Isto significa dizer que, caso exista 
mais de uma resposta para um dado problema, a alternativa mais simples deve ser escolhida (no caso de inferências filogenéticas, escolher a opção com o menor número de passos evolutivos).

A reconstrução das relações de parentesco entre organismos depende da escolha e análise de um tipo particular de característica, aquela derivada (nova) e compartilhada entre dois ou mais táxons, chamada sinapomorfia. Utilizando este critério, seria possível diferenciar grupos chamados de "naturais" (monofiléticos) de agrupamentos artificiais, que não refletem a evolução e diversificação de uma linhagem (completa, incluindo todos os seus integrantes) no tempo. Os critérios objetivos, coerentes e de fácil compreensão propostos por Hennig para a classificação dos organismos foram difundidos (principalmente depois de seu livro escrito em alemão ter sido traduzido para o inglês, em 1966) e amplamente utilizados por taxonomistas em todo o mundo.

A importância da taxonomia clássica (morfológica) é indiscutível e seu emprego resolve a maioria dos problemas de identificação que ocorrem. Entretanto, há situações em que sua utilização pode não ser suficiente. Por exemplo, em estudos filogenéticos, estruturas homólogas entre os organismos estudados devem ser determinadas. No entanto, a comparação de espécies filogeneticamente muito distantes pode ser difícil (às vezes impossível) e comprometerá qualquer tentativa de avaliação da relação de parentesco entre os organismos. Situações que envolvam a existência de espécies crípticas (morfologicamente indistinguíveis) são outro exemplo. Evidentemente, a taxonomia morfológica apresentará limitações nestes casos.

Nas duas situações mencionadas acima (assim como em outras que serão apresentadas neste capítulo), a utilização de marcadores moleculares poderá levar à geração de resultados mais robustos. Neste capítulo, descreveremos os marcadores mais utilizados em sistemática molecular com ênfase nos mais informativos e, consequentemente, mais empregados atualmente. A aplicabilidade, as vantagens e desvantagens de cada técnica serão apresentadas e ilustradas com problemas reais relacionados à sistemática de triatomíneos.

\section{Introdução à sistemática molecular}

De acordo com Mayr (1969), a sistemática pode ser dividida em três categorias: I - a sistemática alfa (a), destinada à detecção e descrição de espécies (taxonomia); II - a sistemática beta ( $\beta$ ), destinada ao estudo do relacionamento entre espécies e sua classificação (filogenia); e III - a sistemática gama (y), destinada ao estudo da variação genética em populações de uma ou mais espécies (genética de populações).

A sistemática molecular é o produto contemporâneo de duas grandes áreas da biologia: a sistemática e a genética molecular. Informações de base genética dos organismos, sejam provenientes de DNA ou RNA, podem ser úteis para a correta identificação e descrição da biota e na geração de conhecimento dos padrões naturais (como a correta distribuição geográfica de uma espécie e a variabilidade genética de suas populações) que, por sua vez, servirão de base para o entendimento de processos evolutivos (como a formação de barreiras de isolamento reprodutivo, eventos de especiação ou ainda resistência vetorial aos inseticidas). Existe ainda a possibilidade de usar toda a informação contida no genoma para inferir a história evolutiva do ser vivo (obtendo-se muito mais caracteres do que os utilizados na morfologia) e de identificar as relações de parentesco em 
qualquer nível taxonômico. A escolha da técnica molecular e do marcador a ser utilizado depende da pergunta científica proposta.

A sistemática molecular foi impulsionada nas últimas quatro décadas principalmente por duas grandes descobertas metodológicas para análise dos genótipos: a mobilidade eletroforética de enzimas (isoenzimas) e a reação em cadeia da polimerase (do inglês Polymerase Chain Reaction ou PCR).

Vetores da doença de Chagas têm sido alvos de estudos de sistemática molecular há aproximadamente 30 anos resultando na publicação de 90 artigos científicos. Embora este tipo de análise possa gerar informações de "ciência básica" como, por exemplo, a determinação do relacionamento evolutivo entre as espécies, o emprego das técnicas de sistemática molecular possibilita a investigação de questões aplicáveis ao controle vetorial. Como exemplos de estudos aplicados à vigilância entomológica podem ser citados (1) a identificação de espécies crípticas (que podem ter papéis epidemiológicos distintos) e (2) a identificação da fonte de reinfestação das casas previamente tratadas com inseticidas.

\section{Isoenzimas}

A associação das técnicas de eletroforese de proteínas em géis de amido e coloração histoquímica de enzimas levou Hunter \& Markert a descreverem as isoenzimas, em 1957, e a promoverem uma revolução no entendimento dos processos evolutivos. Os autores definiram as isoenzimas como sendo "variantes distintas de uma mesma enzima, com as mesmas funções e presentes em um mesmo indivíduo". Estas "variantes" são modificações nas sequências de aminoácidos que, por sua vez, alteram as propriedades físico-químicas das enzimas.

As alterações das propriedades físico- químicas modificam a mobilidade eletroforética das izoenzimas. Quando submetidas a um campo elétrico (eletroforese em géis de amido), as moléculas com cargas e tamanhos diferentes migram diferentemente no gel. Quanto maior a carga elétrica de uma proteína, mais rápido a sua migração no gel em direção ao eletrodo de carga contrária. Para observar a posição destas enzimas, o gel é submetido a uma coloração histoquímica (Figura 13.1).

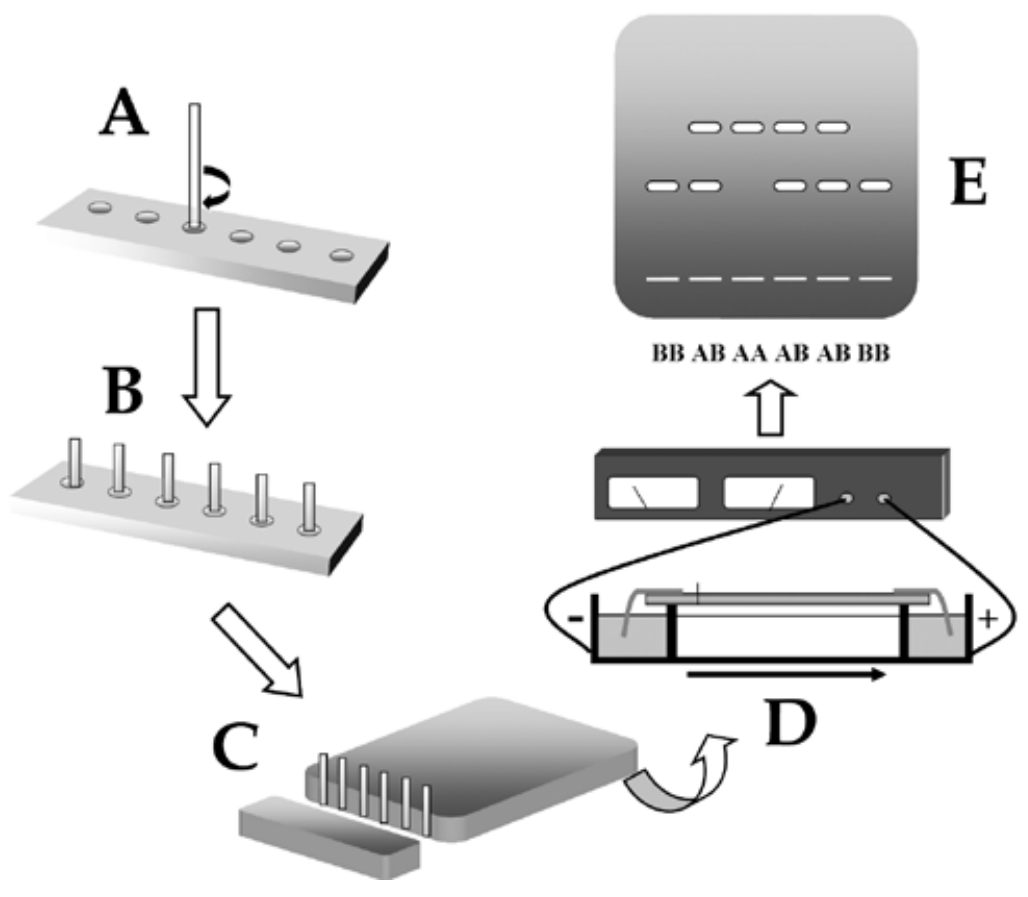

Figura 13.1. (A e B) Um papel de filtro é embebido no extrato proteico extraído dos tecidos de cada espécime. (C) O gel de amido é cortado próximo à sua origem, onde são colocados os papéis de filtro. (D) O gel é submetido a uma eletroforese. A porção do gel contendo as amostras ficará mais próxima do polo negativo, devido à carga negativa do extrato, para que migre para direção oposta. (E) Após a eletroforese, o gel é fatiado longitudinalmente. Cada fatia poderá então ser revelada por diferentes colorações histoquímicas. Neste gel, são mostrados três genótipos distintos: $A A$ (uma única banda na região superior do gel), $B B$ (uma única banda na região inferior do gel) e $A B$ (fenótipo intermediário, com as bandas dos alelos A e B visíveis). 
Nove anos após a descrição da eletroforese de isoenzimas, Lewontin \& Hubby aplicaram esta técnica pela primeira vez em estudos populacionais, utilizando Drosophila pseudoobscura como modelo. Ao descrever uma nova forma de examinar o polimorfismo (heterozigosidade) presente em diferentes populações, uma nova área na biologia estava sendo criada: a sistemática molecular.

As isoenzimas são codificadas por diferentes alelos de um determinado locus e estes alelos podem ser detectados em diferentes regiões do gel. Por ser um marcador codominante, é possível visualizar três fenótipos distintos por mobilidade eletroforética diferencial: homozigoto para um alelo ( $p . e$. dois alelos " $\mathrm{A}$ "), homozigoto para outro alelo (p.e. dois alelos "B") ou heterozigoto (Figura 13.1).

De acordo com Lewontin (1991), até 1984 mais de 1100 espécies tiveram loci isoenzimáticos analisados com o objetivo de se estudar genética populacional e determinar o limite de espécies. Contudo, particularmente em estudos populacionais ou entre espécies de triatomíneos filogeneticamente próximas, o número de loci isoenzimáticos polimórficos tende a ser muito baixo ou nulo e, por isso, deve-se evitar o uso desta técnica para análises de sistemática alfa ou gama. Um exemplo que ilustra essa limitação é o caso de $R$. robustus e $R$. prolixus. Apesar de apresentarem relevâncias epidemiológicas distintas, uma vez que $R$. robustus é exclusivamente silvestre e $R$. prolixus frequentemente coloniza domicílios, são espécies crípticas que não apresentam sequer um locus isoenzimático que as diferenciem (Harry 1993, 1994). Por muitos anos, a validade taxonômica de $R$. robustus como uma espécie distinta de $R$. prolixus foi questionada e este impasse só chegou ao fim após o uso da técnica de sequenciamento de DNA (a ser comentada mais adiante).

Por ser um marcador tradicional, de baixo custo, codominante e poder gerar simultaneamente informações sobre vários loci, a eletroforese de isoenzimas foi muito utilizada para responder questões sobre sistemática de triatomíneos. A partir da primeira década do século XXI esta técnica foi sendo gradualmente substituída pelo sequenciamento de DNA e pela análise de microssatélites em estudos de sistemática alfa e gama, respectivamente. As grandes motivações para esta mudança foram o baixo polimorfismo encontrado nos loci isoenzimáticos quando populações de uma mesma espécie ou espécies de triatomíneos filogeneticamente próximas eram comparadas, além da diminuição dos custos com o sequenciamento e análise de microssatélites.

Quando se pretende realizar experimentos com isoenzimas, muitos cuidados devem ser tomados em relação à estocagem das amostras e análise dos dados. As amostras devem ser frescas ou congeladas. Para executar a técnica de eletroforese (montagem do gel e coloração histoquímica) é necessária muita prática, assim como a interpretação da migração diferencial dos alelos nos géis.

\section{Técnicas que utilizam como base a Reação em Cadeia da Polimerase (PCR)}

Após a utilização das isoenzimas como marcadores moleculares, o segundo grande marco na sistemática molecular foi a descrição do método de amplificação do DNA in vitro, desenvolvido por Kleppe et al. (1971) e posteriormente aprimorado por Mullis (Figura 13.2). A amplificação de uma sequência curta de DNA in vitro (cerca de 300 pares de bases) foi feita primeiramente com o uso de um fragmento da enzima DNA polimerase I (fragmento de Klenow) de bactérias Escherichia coli. A enzima foi utilizada para a polimerização de novas fitas de DNA a partir de uma 
fita molde de um dado organismo. Desta maneira, Kleppe et al. (1971) conseguiram quadruplicar a quantidade inicial do material genético inicialmente colocado na reação.

Contudo, esta descoberta não recebeu muita atenção da comunidade científica, pois apresentava muitas limitações. Para cada ciclo posterior à desnaturação da dupla fita do DNA alvo, uma nova alíquota da polimerase precisava ser adicionada. Como os ciclos de desnaturação térmica da dupla fita de DNA ultrapassam os $90^{\circ} \mathrm{C}$, a desnaturação da polimerase de $E$. coli era inevitável. A necessidade da adição da enzima a cada ciclo impossibilitava a automação do processo, aumentava consideravelmente a chance de contaminação da reação, além de dificultar em muito o trabalho.

Mullis (1985) resolveu o problema da desnaturação da dupla fita do DNA alvo ao utilizar uma DNA polimerase termorresistente extraída da bactéria Thermus aquaticus na amplificação do DNA. Esta nova polimerase, "Taq polimerase", possui temperatura ótima quase duas vezes maior que a de $E$. coli. Seu emprego revolucionou a técnica de $P C R$, possibilitando um grande avanço nos estudos de biologia molecular de um modo geral, e rendeu a Mullis o Prêmio Nobel de Química de 1993.

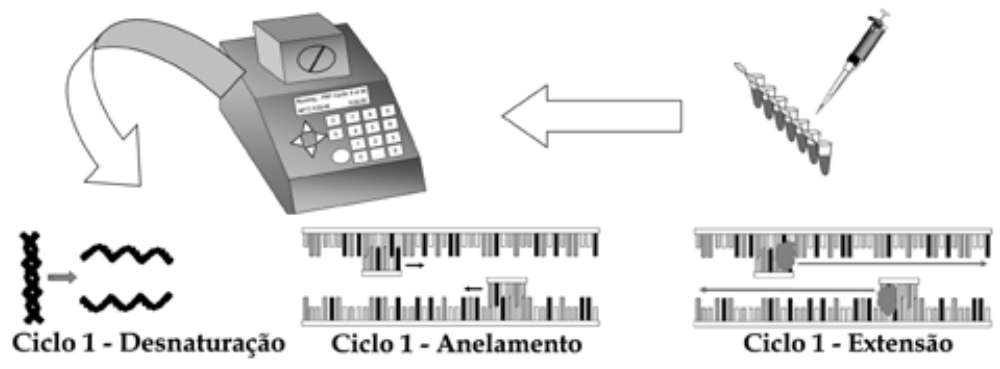

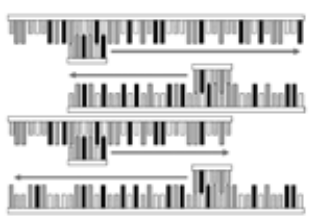

Ciclo 2 - Anelamento

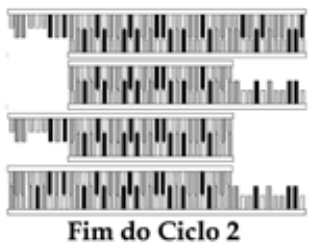

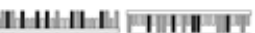
IIIIII IIIII|

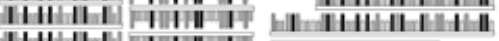
IIIIII I

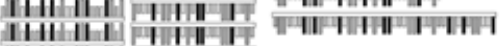
HIIII-1 111 IIII 1.073.741.766 moléculas-alvo 60 moléculas mais longas Fim do Ciclo 30

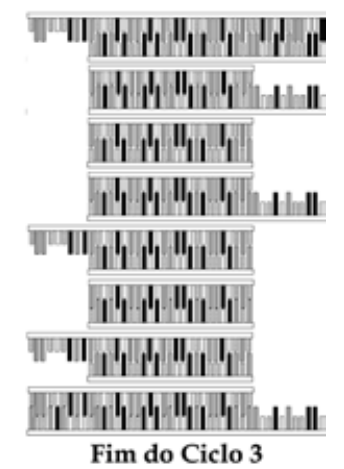

Figura 13.2 - Ao DNA extraído de cada espécime, colocados em tubos individualmente, são acrescentados os reagentes necessários à PCR: tampão (para estabilizar o pH da reação), primers (que se anelarão às fitas de DNA molde em suas regiões complementares), Taq polimerase (enzima que sintetizará as cópias do DNA molde), dNTPs (nucleotídeos que serão incorporados pelas enzimas polimerase às novas fitas) e cloreto de magnésio (co-fator da Taq polimerase, para seu bom funcionamento). Estas reações são colocadas em um termociclador, onde são submetidas a diferentes ciclos de temperatura, para a desnaturação da dupla-fita de DNA (para a abertura da dupla-fita; de 94 a $96^{\circ} \mathrm{C}$ ), anelamento dos primers (encaixe em sua região complementar na fita-molde de DNA; de 45 a $65^{\circ} \mathrm{C}$ ) e extensão (para a síntese das novas fitas de DNA; a $72^{\circ} \mathrm{C}$ ). Este ciclo de temperatura se repete de 20 a 35 vezes. No segundo ciclo são produzidas duas cópias da região alvo, flanqueada pelos primers. Ao fim de 30 ciclos, mais de um bilhão de cópias da região alvo são produzidas.

Durante a década de 80 foram desenvolvidas diversas técnicas moleculares baseadas na PCR capazes de fornecer informações sobre o genótipo dos indivíduos analisados: RAPD, PCR-RFLP, análise de microssatélites e o sequenciamento de DNA. A capacidade de amplificação de determinados genes a partir de apenas quantidades ínfimas de material biológico possibilitou a análise genética de amostras secas (espécimes alfinetados de coleções entomológicas, por exemplo), mal preservadas, ou muito antigas.

As técnicas com base na PCR vêm sendo fundamentais para o avanço do conhecimento sobre os triatomíneos e consequentemente para o desenvolvimento de estratégias racionais de controle vetorial. A seguir, descreveremos cada uma das quatro técnicas mencionadas e sua aplicabilidade potencial na sistemática molecular de vetores de Chagas. 


\section{RAPD}

O “DNA polimórfico amplificado ao acaso", ou RAPD, tem como princípio a amplificação pela PCR de regiões aleatórias do DNA. Ou seja, não é preciso ter qualquer informação prévia sobre a região a ser amplificada. A estratégia consiste na utilização de primers decâmeros (compostos por dez nucleotídeos) cujas sequências foram geradas aleatoriamente.

Quando as amostras de DNA são submetidas à $P C R$, os primers se anelam às regiões do DNA molde que sejam complementares. Estes primers serão fundamentais para a síntese de uma nova fita de DNA, uma vez a enzima polimerase necessita de ao menos um segmento de DNA dupla fita para iniciar o processo de replicação. Ao final da reação, são amplificadas bilhões de cópias das regiões que os primers flanquearam. Temperaturas de anelamento baixas são utilizadas propositalmente, a fim de reduzir a estringência (especificidade).

Após a PCR, as amostras são aplicadas em géis de poliacrilamida e submetidas a um campo elétrico (eletroforese). A molécula de DNA possui carga negativa, devido aos grupamentos fosfato em sua estrutura e, portanto, as amostras devem ser aplicadas no gel próximas ao polo negativo. Quando a corrente elétrica é ligada, as amostras são repelidas pelas cargas negativas e atraídas pelas cargas positivas. Os fragmentos com menor tamanho (isto é, regiões com menor quantidade de pares de bases amplificadas) passam mais rapidamente pela malha do gel e, portanto, distanciam-se mais da origem.

A análise dos géis de RAPD consiste na comparação de todas as regiões genômicas amplificadas (bandas no gel) dos diferentes indivíduos testados. Bandas de mesmo tamanho (mesma distância percorrida) são consideradas como alelos pertencentes ao mesmo locus (um dos pressupostos da técnica), ou seja, a comparação é feita observando-se a presença ou ausência de bandas dispostas em uma mesma linha horizontal. O polimorfismo genético é interpretado de maneira binária. À presença de produto amplificado (bandas) para um determinado locus se confere a designação "1" (presença de banda), enquanto que a ausência de bandas receberá designação "0" (Figura 13.3).

Pode-se dizer que a técnica de RAPD atingiu seu "apogeu" em estudos de sistemática molecular de triatomíneos durante o período compreendido entre os anos 2000 e 2005. A vantagem de gerar informação simultânea sobre muitos loci e indivíduos por um baixo custo (e sem a necessidade de se conhecer previamente a região amplificada) levou muitos pesquisadores a utilizar esta técnica molecular. Contudo, o RAPD contém diversas limitações

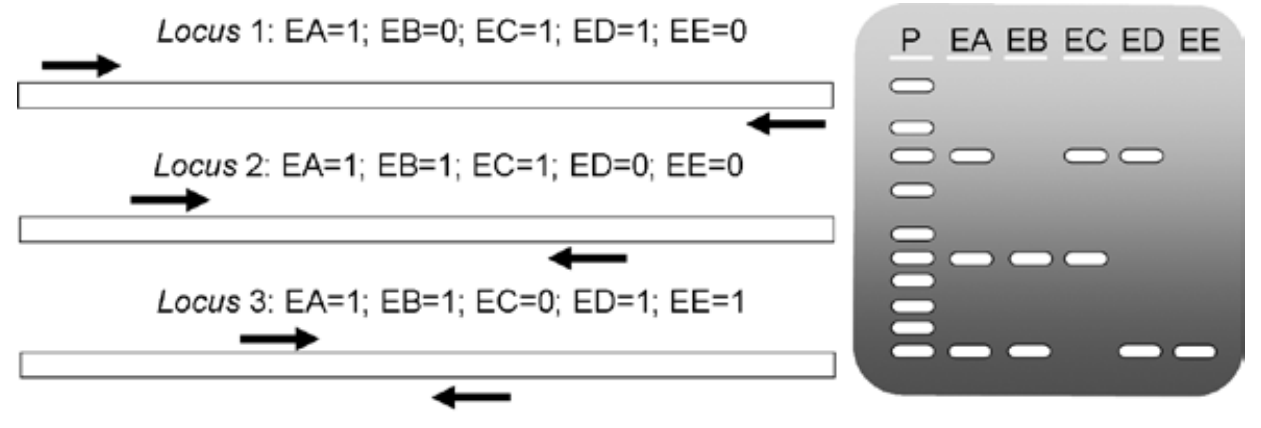

Figura 13.3. Reação de RAPD. Neste caso é mostrado um exemplo de uma reação de PCR com um par de primers aleatórios (setas para esquerda e direita), anelados às suas regiões complementares na fita molde em três loci distintos. Após uma eletroforese em gel, é possível comparar o padrão de bandas das cinco espécies distintas (neste caso, "EA", "EB", "EC", "ED" e "EE"). Caso exista alguma mutação na região do DNA molde complementar a sequência do primer, o mesmo não anelará. $P$ - padrão de tamanho dos fragmentos; EA - espécie $A$; EB - espécie B; EC - espécie C; ED - espécie D; EE - espécie $E$. 
e seu uso exige cautela. Por ser um marcador dominante (Figura 13.4), não é possível diferenciar o homozigoto do heterozigoto. Problemas relacionados à reprodutibilidade dos resultados são frequentes. A qualidade e a concentração do DNA, variações mínimas nas concentrações dos reagentes utilizados na PCR, temperatura e tempo de cada ciclagem da reação podem influenciar no resultado final. Desta maneira, amostras com genótipos idênticos podem apresentar perfis de bandas distintos.

Devido à subjetividade da análise e aos problemas com a reprodutibilidade dos resultados, periódicos científicos conceituados desencorajam a submissão de artigos nos quais se tenha utilizado exclusivamente a técnica de RAPD. Com a diminuição dos custos associados ao sequenciamento de DNA, uma técnica muito mais informativa, o RAPD caiu em desuso.

Se as premissas inerentes à técnica de RAPD forem respeitadas e os problemas de reprodutibilidade minimizados, esta técnica pode ser útil na determinação do limite entre espécies filogeneticamente próximas (estudos de taxonomia alfa). O trabalho de Jaramillo et al. (2001) é um bom exemplo da aplicabilidade do RAPD na taxonomia alfa de triatomíneos. Neste estudo os autores constataram que as populações silvestres de Rhodnius da região de Tolima, na Colômbia, antes identificadas como $R$. prolixus, representavam na realidade uma espécie nova, $R$. colombiensis.

\section{PCR-RFLP}

O polimorfismo de tamanho dos fragmentos de restrição, ou RFLP (sua sigla em inglês), é uma técnica relativamente simples e de baixo custo que, ao contrário do RAPD, consiste na amplificação pela PCR de uma região do DNA conhecida e subsequente corte. Utilizando-se um par de primers complementares a sítios específicos do DNA, amplifica-se a região-alvo. Posteriormente, as cópias desta região-alvo são digeridas por enzimas extraídas de bactérias chamadas endonucleases de restrição. Essas endonucleases reconhecem e cortam sítios específicos (normalmente de quatro a seis pares de base) da região-alvo, gerando fragmentos que podem ser separados por tamanho após eletroforese em gel de agarose (ou poliacrilamida). Milhares de endonucleases de restrição já foram isoladas e maiores informações a respeito destas enzimas podem ser encontradas na base de dados REBASE. Mas como é possível uma enzima digerir regiões homólogas do DNA de diferentes 
espécies e gerar fragmentos de tamanhos distintos? Isto se deve aos eventos de mutação que podem ocorrer nos sítios de clivagem das enzimas de restrição. (Figura 13.5).

Este método pode ser aplicável na detecção de espécies (taxonomia alfa), mas seu uso deve ser evitado em estudos populacionais e filogenéticos. O problema do seu uso em estudos populacionais é que as sequências de indivíduos da mesma espécie serão muito parecidas (ou mesmo idênticas) entre si, inclusive nos sítios de clivagem reconhecidos pelas endonucleases. Isso comprometerá a detecção de variabilidade. Já no caso de estudos filogenéticos, o problema deve-se a limitação de se usar padrões fenotípicos de bandas em um gel para inferir o grau de parentesco entre espécies.

A técnica de PCR-RFLP foi empregada em apenas três trabalhos
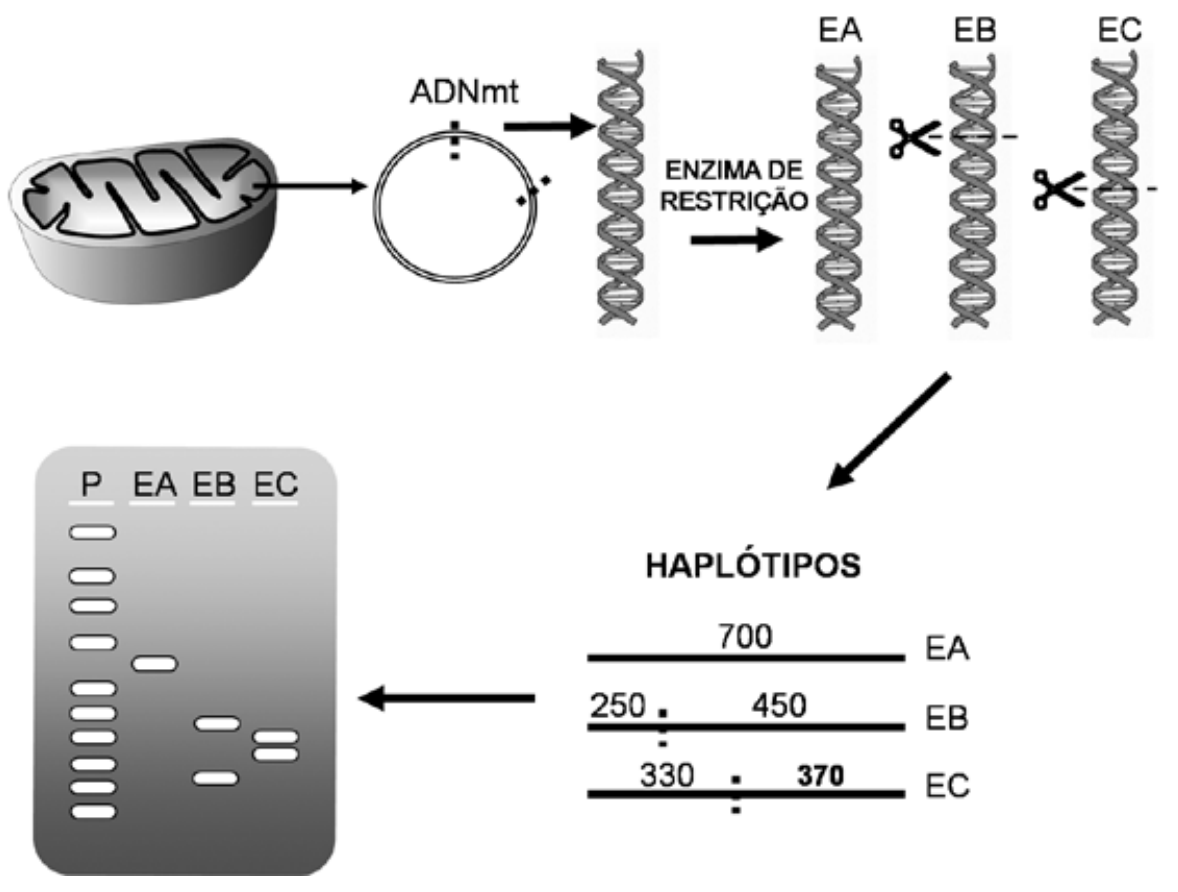

Figura 13.5. Análise da PCR-RFLP. Após a amplificação pela PCR de uma região mitocondrial de 700 pares de base $(\mathrm{pb})$, o produto foi submetido à clivagem por uma enzima de restrição. Esta endonuclease só clivará o fragmento se encontrar uma região nucleotídica específica (de 3 a 8 nucleotídeos), chamada sítio de clivagem. Neste caso, o haplótipo "EA" sofreu eventos de mutação neste sítio e a endonuclease não clivou 0 fragmento de $700 \mathrm{pb}$. No caso de "EB", a endonuclease encontrou o sítio de clivagem numa região a $250 \mathrm{pb}$ do início do fragmento total. Em "EC", este mesmo sítio foi reconhecido a 330pb após o início. Desta forma, após a eletroforese dos produtos, foi possível separar as três espécies pelo perfil de bandas ("EA" - uma banda de 700pb; "EB" - uma banda de $250 \mathrm{pb}$ e outra de 450 ; e "EC" - uma banda de $330 \mathrm{pb}$ e outra de $370 \mathrm{pb}$ ).

(Tartarotti \& Ceron 2005, Naegele et al. 2006, López et al. 2007), e com o barateamento dos custos do sequenciamento de DNA, a tendência é a de que ela caia em desuso em muito pouco tempo.

Uma aplicabilidade relativamente simples, porém útil do PCR-RFLP, está na diagnose molecular de espécies com morfologia semelhante, como fizeram Naegele et al. (2006). Para quem não é especialista em morfologia de triatomíneos, a diferenciação entre Rhodnius pictipes e Rhodnius stali pode não ser trivial. Através da amplificação do segundo espaçador interno ribossomal (ITS-2), os autores conseguiram separar as duas espécies utilizando duas das onze endonucleases testadas.

Seria interessante se um método simples, de baixo custo e de rápida execução como o PCR-RFLP fosse utilizado para a detecção de espécies crípticas. Contudo, o baixo polimorfismo detectado na análise dificulta a aplicação do PCR-RFLP nestes casos.

\section{Microssatélites}

Em 1987 surgiu uma nova forma de se genotipar espécimes. A descoberta de regiões hipervariáveis do DNA, ou sequências "satélites", contribuiu para o avanço nos estudos intraespecíficos (ou populacionais). 
O termo "satélite" foi criado nos anos 60, para descrever uma fração do DNA que apresentava um sobrenadante de densidade distinta das demais quando submetido à centrifugação em gradiente. Esta região era caracterizada por apresentar repetições sequenciais (in tandem) de nucleotídeos, chamados motifs (de 10-50pb). Posteriormente, regiões repetitivas de motifs um pouco menores (10 a 30pb) foram descobertas e denominadas de "minissatélites". Finalmente, em 1981, regiões com repetições sequenciais de um a seis pares de bases foram encontradas e denominadas "microssatélites".

Mas como essas regiões de repetição sequencial são originadas? As células são estruturas complexas e requerem um perfeito sincronismo entre organelas e enzimas para funcionarem corretamente e responder bem aos estímulos externos. Neste "espetáculo microscópico", todos os participantes parecem bem orquestrados e à prova de erros. Mas nem sempre é assim. O esforço repetitivo de uma ação pode induzir o erro. Charles Chaplin foi genial em sua atuação no filme "Tempos Modernos" (1936), mostrando como um trabalhador de uma fábrica pode enlouquecer após muitas horas de jornada de trabalho executando a mesma tarefa - aparafusar porcas. Se, ao sair da fábrica, por ventura visse objetos semelhantes a porcas, como botões de camisa, Chaplin não pensava duas vezes e tentava "aparafusá-los" também. Dentro das células, as enzimas DNA polimerase podem ter seus momentos de Charles Chaplin e se equivocarem durante a fase de replicação do DNA. Estes momentos são chamados de "escorregadas da polimerase".

A replicação do DNA é um processo de duplicação do material genético. Uma das fitas (fita mãe) é usada como molde para a síntese de uma fita complementar (fita filha). A enzima DNA polimerase é responsável pela leitura da fita mãe e encaixe do nucleotídeo complementar correto na nova fita. Contudo, em regiões de repetição (chamadas de satélites), a polimerase tende a errar com uma maior frequência, às vezes incorporando repetições nucleotídicas a mais, como também deixando de incorporá-las devidamente (Figura 13.6). Estes "erros" são normalmente corrigidos pelo mecanismo de reparo do núcleo (proofreading). Ocasionalmente, porém, alguns destes erros passam despercebidos e permanecem no genoma. Quando as "escorregadas da polimerase" ocorrem em células germinativas, esses "erros" são herdados pela próxima geração.

Tão logo se percebeu que a variabilidade alélica destas regiões de repetição exibia codominância e segregava mendelianamente, os microssatélites passaram a substituir as isoenzimas em estudos populacionais (Figura 13.7). Para analisar os microssatélites, é necessário amplificar pela PCR os loci que contenham regiões de microssatélites. $A$ esta reação de PCR, é acrescentado um par de primers específicos que flanqueiem a região de repetição. Após a amplificação dos fragmentos pela PCR, os alelos de cada locus são

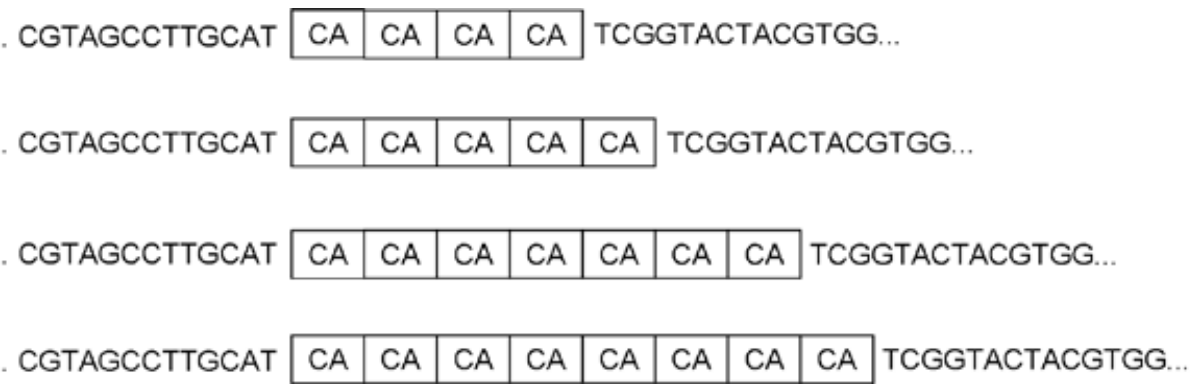

Figura 13.6. "Escorregadas" da DNA polimerase. Neste exemplo de uma região de microssatélites, quatro espécimes foram coletados. A região de microssatélites ancestral continha quatro repetições dos nucleotídeos "CA". Contudo, apenas um espécime continha o mesmo numero de repetições "CA" que 0 ancestral. Devido às escorregadas da polimerase, foram incorporadas novas repetições nas sequências dos outros três espécimes (uma na segunda sequência, três na terceira e quatro na quarta sequência). 
analisados em um sequenciador automático. Os primers utilizados na reação são marcados com fluorescência para que as regiões de microssatélites amplificadas sejam detectadas.

No interior do sequenciador ocorre uma espécie de eletroforese. Ao invés das amostras percorrerem um gel de poliacrilamida, elas são aplicadas em uma placa de 96 poços (cada poço contendo uma amostra individual). Para cada poço, existirá um capilar preenchido por um polímero específico. A eletroforese se inicia após a aplicação de um campo elétrico aos capilares que fará com que as moléculas de DNA migrem pelo seu interior até chegarem a uma "janela de detecção". Os alelos menores migram mais rápido que os maiores e à medida que vão passando por esta "janela", são estimulados por um laser de árgon e emitem a fluorescência. Uma série de lentes (espelhos) direciona e foca as emissões fluorescentes num espectrógrafo, onde serão separadas em função do comprimento de onda. Na medida em que os alelos marcados passam pelo laser, um computador compara o tamanho do alelo amplificado com um padrão para que seja determinado o seu tamanho. Ao final da reação, um arquivo de saída mostrará os picos de fluorescência contendo os tamanhos dos dois alelos de cada locus.

As grandes desvantagens ao utilizar estes marcadores são o alto consumo de tempo e dinheiro para encontrar regiões de repetições nucleotídicas in tandem no genoma e desenvolver novos primers que flanqueiem estes loci. Já existem caracterizados e descritos primers para $R$. pallescens (10 loci), $R$. ecuadoriensis (6 loci), R. prolixus (20 loci), R. robustus (10 loci), T. brasiliensis (6 loci), T. dimidiata (8 loci), T. infestans (19 loci) e T. pseudomaculata (6 loci; Harry et al. 1998, 2008a, 2008b, 2009, Anderson et al. 2002, García et al. 2004, Marcet et al. 2006, Fitzpatrick et al. 2009).

Análises moleculares vêm sendo utilizadas há mais de trinta anos com o objetivo de estudar relações intraespecíficas, mas para que se tenham estudos genealógicos ou genético populacionais mais refinados, torna-se necessária a utilização de marcadores altamente polimórficos, como os microssatélites. A partir dos resultados desses marcadores codominantes (Figura 13.7), é possível estimar o fluxo gênico entre populações de forma mais apurada, e consequentemente, avaliar as capacidades de dispersão de triatomíneos.

Um exemplo de como estes marcadores podem ser úteis em monitoramentos de áreas tratadas com inseticidas é o trabalho feito por Richer et. al (2007), com populações de $T$. infestans dos Andes bolivianos (a 2700 metros de altitude). Sabe-se que em regiões bolivianas de baixa altitude (principalmente no Chaco), é comum encontrar casas tratadas com inseticidas sendo reinfestadas por populações silvestres ou recrudescentes de $T$. infestans.

\section{Homozigoto: (as duas fitas têm 7 repetições de CT)}

.... CGTAGCCTTGCATCCTTCTCTCTCTCTCTCTATCGGTACTACGTGG... .... CGTAGCCTTGCATCCTTCTCTCTCTCTCTCTATCGGTACTACGTGG... regiẫo 5 ' flanqueadora locus de microssatélite região 3 ' flanqueadora

Heterozigoto: (uma fita tem 7 repetições de CT e a outra tem 8) . CGTAGCCTTGCATCCTTCTCTCTCTCTCTCTATCGGTACTACGTGG... .CGTAGCCTTGCATCCTTCTCTCTCTCTCTCTCTATCGGTACTACGTGG... região 5' flanqueadora locus de microssatélite região 3' flanqueadora

Figura 13.7. Co-dominância dos marcadores microssatélites. É possível separar os fenótipos resultantes do homozigoto e do heterozigoto. Neste caso, os alelos apresentam uma diferença de dois pares de base em relação aos tamanhos, devido à incorporação em uma das fitas de DNA de uma repetição "CT". 
Contudo, não se sabia como as populações de altitude se comportavam, isto é, se as populações silvestres poderiam recolonizar as casas tratadas com inseticidas ou não. A realidade local era que duas das nove casas de um vilarejo dos Andes bolivianos, previamente tratadas, foram recolonizadas por T. infestans. Com o objetivo principal de se descobrir qual seria a fonte de reinfestação, foram analisados 111 espécimes provenientes de seis microrregiões, sendo cinco silvestres (dentre elas duas de transição, modificadas pelo ser humano) e uma domiciliar. Para a análise, foram utilizados 10 loci de microssatélites.

Os resultados levaram Richer et al. (2007) a concluir que os espécimes das três microrregiões silvestres não modificadas pelo ser humano eram representantes de uma população panmítica, que não transfere genes para as populações presentes nas duas microrregiões de transição, nem para a domiciliada. Da mesma forma, os indivíduos presentes nas duas microrregiões de transição não eram responsáveis pela reinfestação dos domicílios. Além dos dados moleculares, foi observado que em regiões de altitude $T$. infestans praticamente não voa. Como em regiões de altitude o ar é rarefeito e a temperatura é baixa, as populações de $T$. infestans só se locomovem por caminhadas pelas áreas não modificadas pelo ser humano. As regiões com pouca cobertura vegetal ou completamente desmatadas são desfavoráveis para sua sobrevivência e, portanto, populações de áreas silvestres não transitam até as áreas modificadas pelo ser humano. Desta forma, tanto as duas populações das regiões de transição quanto a população domiciliada estariam isoladas. A reinfestação dos domicílios foi, na verdade, consequência do recrudescimento de populações de insetos locais resistentes ao inseticida ou que tenham sobrevivido devido a deficiências técnicas do controle vetorial. Esta descoberta foi muito importante para o sistema de vigilância de vetores local, pois indicava que o tratamento com inseticidas das casas infestadas poderia ser eficaz.

A facilitação do acesso aos microssatélites pode ser de grande importância para o desenvolvimento de novas estratégias de controle e vigilância dos vetores de Chagas. Talvez isto esteja mais próximo do que se imagina: até 2005 , apenas em dois trabalhos publicados com triatomíneos tinham sido utilizados loci de microssatélites. Nos últimos cinco anos, o número de publicações com esses marcadores subiu para 10.

\section{Sequenciamento de DNA}

Esta técnica pode ser considerada como a mais informativa para estudos em sistemática molecular. Por utilizar como matéria-prima o conteúdo genético propriamente dito, os nucleotídeos, o sequenciamento de DNA é objetivo e aplicável em qualquer nível taxonômico, desde que se escolha a região gênica adequada.

No genoma animal é possível encontrar mais de $10^{11}$ pares de nucleotídeos, que podem constituir regiões mais conservadas entre as espécies (i.e. codificam proteínas essenciais à sobrevivência do organismo) ou menos conservadas. Existem dois genomas distintos: o nuclear (herdado do pai e da mãe) e o mitocondrial (de herança materna).

O genoma nuclear pode ser dividido, de maneira simples, em éxons e íntrons. Os éxons são regiões codificantes de aminoácidos e geralmente muito conservadas. A baixa taxa de mutação se deve ao eficiente mecanismo de reparo do núcleo (proofreading). Quando a DNA polimerase insere 
no genoma nuclear erroneamente um nucleotídeo e não faz a correção, existem proteínas de reparo que "revisam" esses nucleotídeos inseridos nos éxons e identificam os possíveis erros. Caso exista algum, exonucleases clivam a região complementar errada e a polimerase refaz de maneira correta o fragmento.

Nem todas as mutações resultarão na produção de um aminoácido diferente do original, pois o código genético é degenerado (redundante), ou seja, mais de um códon codifica um mesmo aminoácido (são 64 códons que codificam para 20 aminoácidos; Tabela 13.1). Dependendo da localização desta mutação, a substituição nucleotídica é sinônima. Na maioria das vezes, a substituições na $3^{a}$ posição do códon não altera o aminoácido. Quando a mutação ocorre na $1^{a}$ posição, a codificação de poucos aminoácidos não é alterada, enquanto que qualquer mutação de $2^{a}$ posição de códon obrigatoriamente implicará na codificação de um novo aminoácido. Devido a estes fatores, as mutações ocorrem com maior frequência na $3^{a}$ posição do códon, seguidas pelas de $1^{\mathrm{a}}$ e $2^{\mathrm{a}}$ posições.

A maioria das mutações é desvantajosa, i.e. prejudica a aptidão do indivíduo. Essas mutações são removidas da população por seleção natural purificadora. As demais podem ser neutras (a maioria) ou vantajosas. As neutras não interferem na aptidão do organismo e sua frequência oscila, de geração em geração, na população. As vantajosas são selecionadas positivamente e aumentarão de frequência na população.

O sequenciamento de regiões dos éxons é utilizado, por exemplo, em estudos filogenéticos de espécies mais distantes. Os íntrons são as regiões não codificantes do genoma e, por sofrerem menor pressão seletiva (uma vez que suas sequências não codificam proteínas), são mais variáveis que os éxons. A análise de íntrons pode ser utilizada para taxonomia alfa, filogenia entre espécies próximas e até para genética de populações. Os espaçadores ribossomais internos ITS-1 e ITS-2, localizados entre as regiões 185 e 28S, também são bons marcadores para esses tipos de estudo, tendo sido utilizado para filogenia de espécies do gênero Panstrongylus (Marcilla et al. 2002), taxonomia alfa e filogenia dos complexos T. phyllosoma (Martínez et al. 2006) e T. dimidiata s.l. presentes no México (Tamay-Segovia et al. 2008, Herrera-Aguilar et al. 2009) e genética de populações de T. rubrovaria na Argentina, Brasil e Uruguai (Pacheco et al. 2007).

O genoma mitocondrial não apresenta íntrons e é formado por um único cromossomo circular, contendo genes codificadores de proteínas estruturais e funcionais responsáveis pela
Tabela 13.1 - Aminoácidos produzidos e respectivos códons.

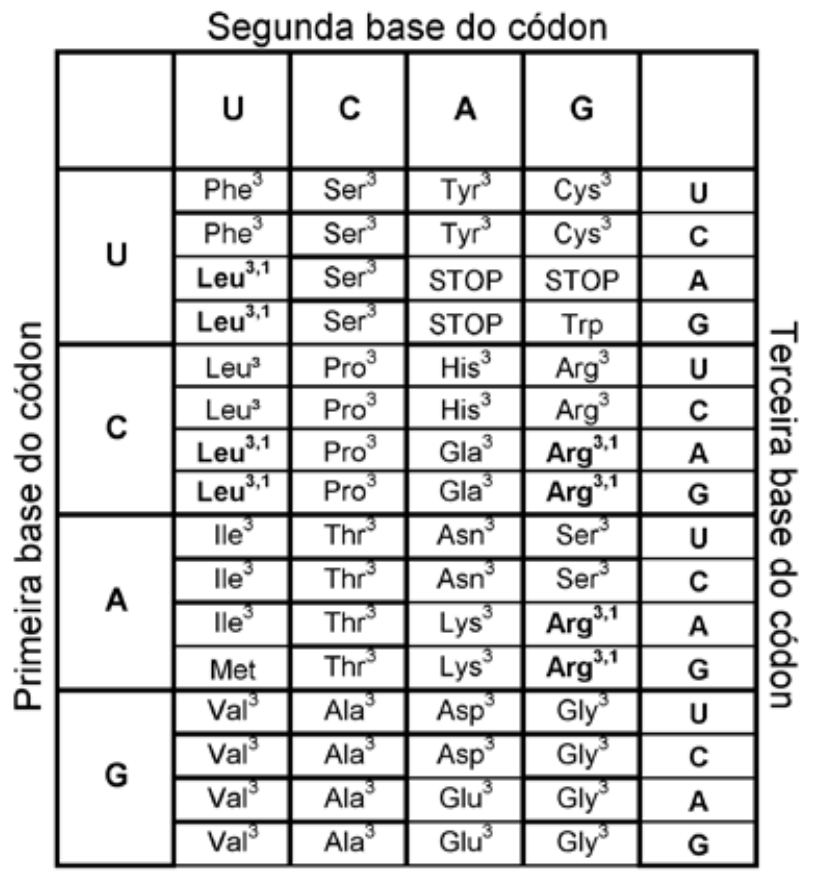

1 mesmo havendo alteração na primeira base do ração na terceira base do códon, o aminoácido é inalterado; U - uracila; C - citosina; A - adenina; G - guanina; Phe Fenilalanina; Leu - Leucina; Ile - Isoleucina; Met - MetioniAla - Alanina; Tyr - Tirosina; His - Histidina; Gla - Glutamina; Asn - Asparagina; Lis - Lisina; Asp - Ácido aspártico; Glu - Ácido glutâmico; Cys - Cisteína; Trp - Triptofano; Arg - Arginina; Gly - Glicina. 
respiração celular. Por não possuir mecanismo de reparo do DNA, sua taxa de evolução é cerca de 10 vezes mais rápida do que a do genoma nuclear, tornando-o mais indicado para estudos populacionais e filogeográficos. O marcador mitocondrial mais utilizado em sistemática molecular de triatomíneos é o gene citocromo $b$ (cyt $b$ ). A partir do sequenciamento de fragmentos do cyt $b$, pelo menos três complexos de espécies crípticas já foram descobertos, como $T$. brasiliensis s.l. (Monteiro et al. 2004, Almeida et al. 2008, Mendonça et al. 2009), R. robustus s.l. (Lyman et al. 1999, Monteiro et al. 2003, Pavan \& Monteiro 2007) e T. rubida (Pfeiler et al. 2006). O cyt $b$ também foi utilizado em estudos populacionais com as espécies T. infestans (Giordano et al. 2005), R. prolixus (Fitzpatrick et al. 2008) e T. dimidiata (Blandón-Naranjo et al. 2010). Neste último com T. dimidiata, os autores demonstraram que o cyt $b$ é mais variável que o ITS-2. Todos os 58 espécimes provenientes de sete localidades da Costa Rica apresentaram a mesma sequência para o marcador nuclear, ao passo que o cyt $b$ revelou um polimorfismo de $10,17 \%$ nas sequências produzidas. Os resultados indicam que o cyt $b$ é o melhor marcador (em relação ao ITS-2) para estudos populacionais.

Existem ainda genes mitocondriais que são mais conservados, como aqueles codificantes das subunidades ribossomais $12 \mathrm{~S}$ e $16 \mathrm{~S}$, e que podem ser úteis em estudos filogenéticos com espécies mais distantes. Estes marcadores já foram utilizados em estudos filogenéticos com espécies do gênero Triatoma (Garcia \& Powell 1998), espécies pertencentes à Subfamília Triatominae (Hypša et al. 2002) ou ainda à Família Reduviidae (Weirauch \& Munro 2009).

Com a exceção dos genes $12 \mathrm{~S}$ e $16 \mathrm{~S}$, o uso dos demais genes mitocondriais em estudos filogenéticos para inferir relacionamentos distantes não é indicado (a menos que sejam excluídas da análise as terceiras posições de códons), por haver eventos de homoplasia entre as sequências (Figura 13.8). Marcadores mitocondriais também não são aconselháveis em estudos sobre híbridos, devido a problemas de introgressão.

Até a década de 70, pesquisadores utilizavam as proteínas como modelo para estudos evolutivos. As primeiras tentativas de sequenciar o DNA foram pouco promissoras, com a análise de pequenos fragmentos de 15 a 20 pares de base. Os cientistas só começaram a ter acesso diretamente a fragmentos maiores em 1977, após as descobertas de Maxam \& Gilbert, e de Sanger et al. sobre novas técnicas de sequenciamento do DNA.

O método de Sanger et al. (1977) consiste na amplificação pela PCR de um fragmento de DNA utilizando um par de primers, e uma posterior reação, que inclui DNA polimerase, nucleotídeos (dinueleotídeos ou dTPs, formados por dATP, dCTP, dGTP e dTTP) e nucleo-

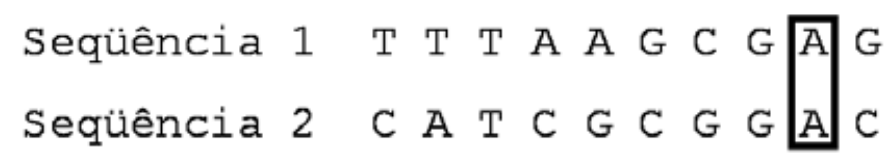

Número de mudanças no mesmo sítio

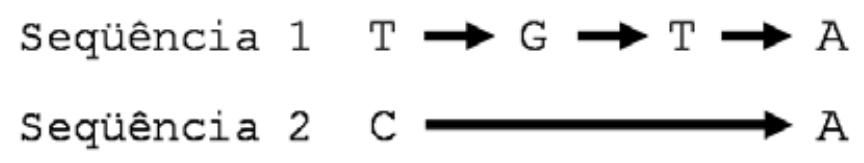

Figura 13.8. Evento de homoplasia. Este é um exemplo de duas sequências pertencentes a duas espécies

filogeneticamente distantes. Note que em dez nucleotídeos, seis diferem entre as sequências. Desta maneira, não há como garantir que os nucleotídeos iguais são conseqüentes de mesma ancestralidade ou apenas eventos de homoplasia. No caso do sítio marcado com o retângulo, o nucleotídeo presente em ambas as sequências é o mesmo, entretanto suas origens são distintas pois sofreram diferentes eventos mutacionais. Para obter a adenina nesta posição, a linhagem da sequência 1 sofreu três eventos de mutação e sua origem inicial era uma timina. Já a linhagem da sequência 2 sofreu apenas um único evento mutacional, alterando uma citosina por uma adenina. 
tídeos modificados e radioativamente marcados (dideóxinucleotídeos ou ddTPs, formados por ddATP, ddCTP, ddGTP e ddTTP).

Para que os dTPs se unam para formar uma fita de DNA, cada nucleotídeo tem em sua extremidade $3^{\prime}$ um grupamento hidroxila $(\mathrm{OH})$. No caso dos ddTPs, não existe este grupamento livre, logo nenhum outro nucleotídeo poderá ser incorporado à fita (Figura 13.9a, b). A reação de sequenciamento de Sanger é separada em quatro tubos, sendo que em cada tubo se coloca os quatro dTPs, DNA polimerase, os primers e um dos quatro ddTPs (num tubo coloca-se o ddATP, em outro o ddCTP, e assim sucessivamente). Desta forma, ao fim da reação, existirão sequências desde o tamanho mínimo até o tamanho máximo do fragmento de DNA amplificado, sempre com um ddTP no fim da fita. Isto porque existem bilhões de cópias do fragmento amplificado e os ddTPs serão incorporados a fita com os dTPs em todas as posições nucleotídicas do fragmento (Figura 13.9c). Estes produtos são submetidos à eletroforese em gel de poliacrilamida (a reação de cada tubo contendo os quatro ddTPs é colocada em poços distintos do gel) e analisados em autorradiografias. Os fragmentos com menor tamanho (i.e. regiões com menor quantidade de pares de bases amplificadas) passam mais rapidamente pela malha do gel e, portanto, migram para a porção inferior. Por conseguinte, os fragmentos maiores migram mais lentamente, e ficam na região superior do gel (Figura 13.9d). A análise da sequência é feita manualmente e despende muito tempo.

O surgimento dos sequenciadores automáticos na década de 90 facilitou a análise de sequências de DNA, pois em apenas quatro horas era possível sequenciar fragmentos de até 1.500 bases (ou 1,5Kb). Nestes equipamentos são utilizados produtos de reação semelhantes aos de Sanger, só que em vez de colocar separadamente os quatro ddTPs radioativamente marcados, são colocados todos os ddTPs marcados com fluorescência num mesmo tubo. As amostras são aplicadas em placas de 96 poços e submetidas à eletroforese em capilares de um sequenciador automático (processo semelhante àquele de análise dos microssatélites). Conforme os fragmentos chegam à "janela de detecção", um laser faz a leitura da fluorescência (cada nucleotídeo emite uma fluorescência distinta) e um programa de computador "traduz" esse pico de fluorescência em um nucleotídeo (Figura 13.9e).

A automação do sequenciamento e o rápido avanço da tecnologia propiciaram maior acessibilidade a esta técnica e, consequentemente, o aumento de seu uso na sistemática molecular. A criação de bancos públicos de sequências na internet, como o GenBank, possibilitaram a comparação de dados gerados por laboratórios de todo o mundo e um maior acúmulo do conhecimento biológico.

As análises por sequenciamento de loci mitocondriais e nucleares foram muito importantes para descobertas de espécies crípticas e monitoramentos de áreas tratadas com inseticidas. Até 1992 existia a dúvida se $R$. robustus era uma espécie válida e diferente de $R$. prolixus, uma vez que não existia sequer um locus isoenzimático capaz de separá-las. Sob o ponto de vista epidemiológico, este seria o pior cenário possível, pois admitia a possibilidade de existência de livre fluxo gênico entre populações silvestres e domésticas. Um dos trabalhos mais relevantes para a resolução desse impasse taxonômico foi o de Lyman et al. (1999), cuja análise de sequências de um fragmento de um gene mitocondrial (cyt $b$ ) foi crucial para a constatação de que $R$. robustus era uma espécie distinta de $R$. prolixus. Esta descoberta sacramentava uma questão muito relevante: que o fluxo gênico entre populações silvestres e domésticas não era tão comum como se imaginava. $R$. robustus era estrita- 


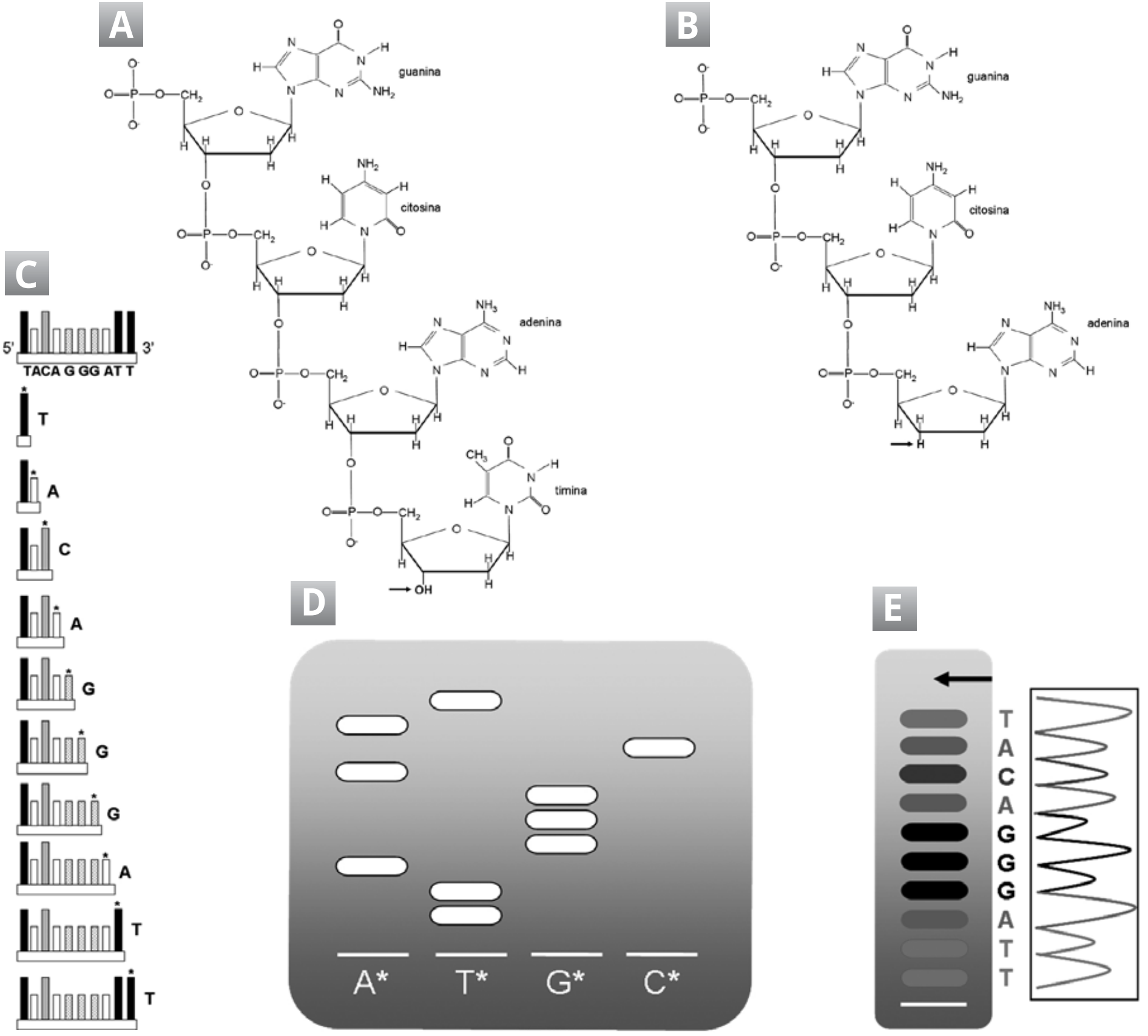

Figura 13.9. (A) Fórmula estrutural dos dinucleotídeos (dNTPs; guanina, citosina, adenina e timina) ligados para a formação de uma fita de DNA. Note que suas estruturas são ligadas no grupamento hidroxila $(\mathrm{OH}$, mostrado com uma seta) em sua porção inferior, onde o hidrogênio $(H)$ é liberado e se liga ao fósforo $(P)$ da estrutura de outro nucleotídeo. (B) Fórmula estrutural contendo dinucleotídeos (guanina e citosina) e um dideoxinucleotídeo (ddTPs; adenina). Note que, ao contrário dos dinucleotídeos, o dideóxinucleotídeo contém apenas um hidrogênio ( $\mathrm{H}$, mostrado com uma seta) em vez de um grupamento hidroxila em sua porção inferior. Desta forma, não há como outro nucleotídeo ser incorporado à fita de DNA. (C) Durante a reação de sequenciamento, aleatoriamente são incorporados dNTPs e ddTPs. Toda vez em que um ddTP é incorporado à fita (marcados com asterisco), não há como incorporar um novo nucleotídeo. Ao fim da reação, serão obtidas fitas de DNA contendo desde 1 pb até o tamanho máximo do fragmento. (D) Método de Sanger, no qual é aplicada em cada poço de um gel de poliacrilamida uma reação contendo todos os dNTPs e apenas um dos ddTPs (dATP, dTTP, dGTP ou dCTP). Ao fim da eletroforese e revelação do gel, é possível reconhecer a sequência do fragmento, fazendo a leitura do menor fragmento (mais distante da origem, marcada com um traço branco) até o maior fragmento (menor distância da origem). (E) Método de seqüenciamento utilizando um sequenciador automático capilar. Por capilaridade, os menores fragmentos chegam mais rapidamente ao laser ótico e suas fluorescências são "traduzidas" em nucleotídeos por um computador. 
mente silvestre e $R$. prolixus era uma espécie majoritariamente doméstica, existindo apenas poucas evidências sobre a existência de populações silvestres de $R$. prolixus na Venezuela. Mais tarde, a partir de um fragmento maior de cyt $b$, Monteiro et al. (2003) constataram que não só $R$. robustus era uma espécie válida, como compreendia um complexo de quatro espécies crípticas (chamadas de $R$. robustus I, II, III e IV; Figura 13.10).

A questão epidemiológica relevante que ainda restara, se $R$. prolixus também poderia ser encontrado no ambiente silves-
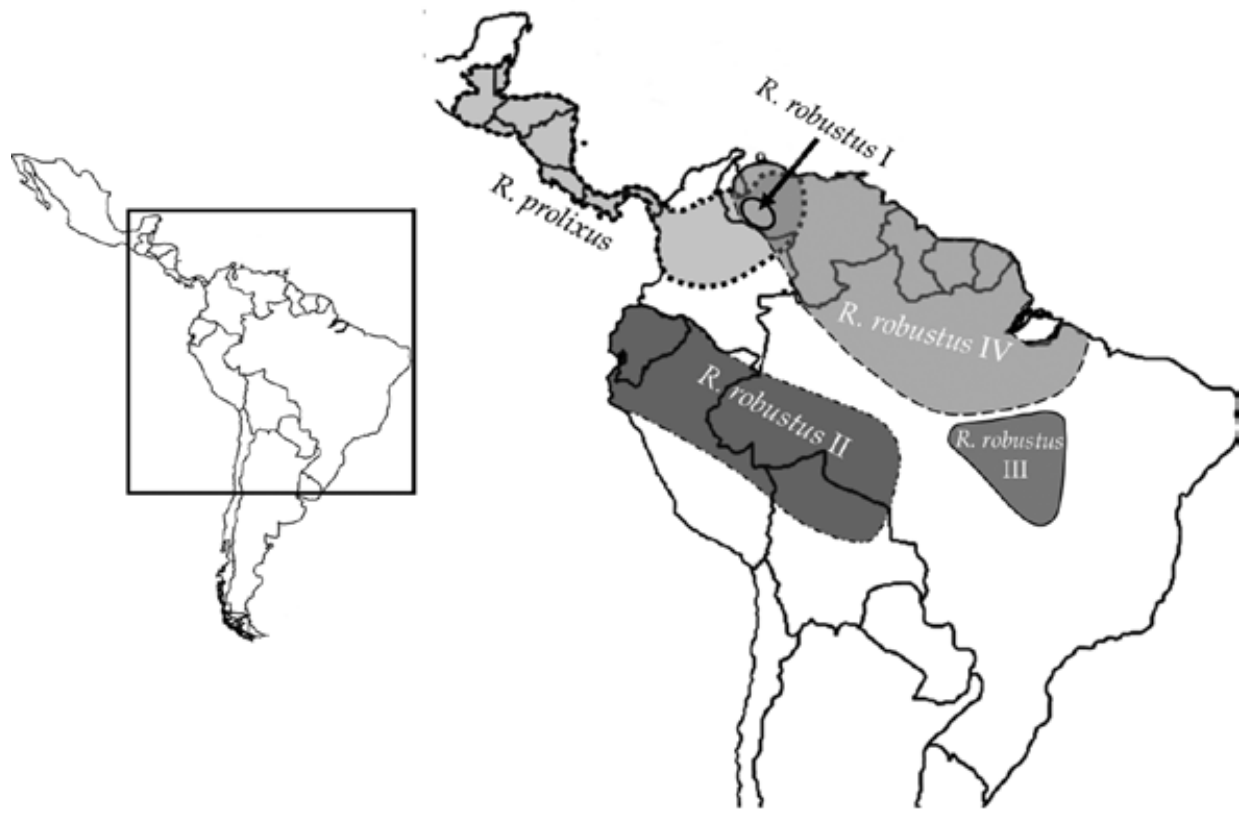

Figura 13.10. Distribuição geográfica de $R$. prolixus e das quatro espécies crípticas de $R$. robustus (I, II, III e IV). Note que $R$. prolixus, $R$. robustus I e $R$. robustus IV são simpátricas na Venezuela, ao passo que $R$. robustus II, III e IV são alopátricas por todas as suas áreas de distribuição. tre, só foi respondida em 2008, quando Fitzpatrick et al., utilizando o mesmo fragmento de cyt $b$ que Monteiro et al. (2003), analisaram a diversidade nucleotídica das sequências de 551 espécimes de 34 populações de $R$. prolixus pertencentes a seis departamentos venezuelanos. Os autores puderam constatar que existiam populações de $R$. prolixus silvestres e que os eventos de colonização das casas por populações silvestres não eram frequentes. Contudo, análises populacionais mais apuradas em microescala geográfica (utilizando microssatélites) indicaram que em cinco ecótopos de dois departamentos da Venezuela existia o fluxo gênico entre as populações de palmeiras e as domiciliadas. Esta descoberta aponta que ações tradicionais de controle vetorial, como aplicação de inseticidas no interior das casas, serão ineficazes nestas regiões.

Outro complexo de espécies confirmado com o uso do sequenciamento foi o de T. brasiliensis s.I. Até 1956, acreditava-se na existência de três subespécies de Triatoma brasiliensis: T. brasiliensis brasiliensis Neiva, 1911, T. b. melanica Neiva \& Lent, 1941 e T. b. macromelasoma Galvão, 1956. Em 1979 Lent \& Wygodzinsky sinonimizaram as três subespécies como T. brasiliensis, considerando que as diferenças entre as três eram apenas cromáticas. Quase 20 anos depois, foi descrita uma nova forma cromática encontrada em Juazeiro, na Bahia. Os resultados de oito loci isoenzimáticos das quatro formas cromáticas de T. brasiliensis (Costa et al. 1997) indicavam que apenas àquela anteriormente nomeada de $T$. $b$. melanica apresentava valores de distância genética interespecíficos quando comparada com as demais formas cromáticas. Portanto, T. b. melanica deveria ser elevada à categoria de espécie.

Sete anos mais tarde, a partir das análises de um fragmento do gene mitocondrial cyt $b$, Monteiro et al. (2004) puderam constatar que ao invés de conter apenas duas espécies, T. brasiliensis s.I. representava um complexo de três espécies distintas: T. brasiliensis, T. juazeirensis [sendo mais 
tarde formalmente descrita por Costa \& Felix em 2007)] e Triatoma melanica (elevando sua categoria de subespécie para espécie por Costa et al., 2006). T. b. macromelasoma representava um morfotipo distinto, mas geneticamente semelhante de $T$. $b$. brasiliensis, e por isso foram mantidas no mesmo táxon, $T$. brasiliensis.

Considerando os estudos de sistemática molecular de triatomíneos, marcadores mitocondriais vêm sendo utilizados com maior frequência, em aproximadamente o dobro de publicações (em 16 utilizou-se mtDNA, enquanto que 7 utilizaram rDNA). Apesar de apenas cinco trabalhos apresentarem resultados de marcadores nucleares concomitantemente com os mitocondriais, esta é a alternativa mais indicada. O genoma mitocondrial é herdado somente pela linhagem materna e a descoberta de híbridos naturais só poderá ser feita se um marcador nuclear também for utilizado.

\section{Projeto Genoma versus Custo do Sequenciamento}

Nos últimos 10 anos, 1.214 genomas completos de espécies de animais e plantas já foram sequenciados e outros 6.911 projetos estão em andamento (disponível na página web "GOLD Genomes Online Database v 3.0"). Este salto tecnológico promovido pela biologia molecular e tecnologias de última geração possibilitará um grande avanço para o conhecimento da biologia, bioquímica e comportamento de vários organismos. Novos alvos moleculares poderão ser isolados a partir destes genomas, possibilitando o desenvolvimento de estratégias mais racionais para o controle de pestes agrícolas ou vetores de doenças. O primeiro projeto com um triatomíneo foi iniciado em 2006, sob a coordenação de Erwin Huebner, da Universidade de Manitoba, no Canadá, e financiamento dos National Institutes of Health dos EUA. O genoma completo de R. prolixus tem 670 mil quilobases, a informação sobre a decodificação está à disposição da comunidade científica em: www.vectorbase.org.

O primeiro passo em uma pesquisa científica é a correta identificação da espécie a ser estudada. Algumas espécies pertencem a complexos de espécies crípticas e sua identificação irá requerer o seqüenciamento de regiões nucleares ou mitocondriais. Como nem todos têm acesso a esta técnica, torna-se relevante a criação de métodos alternativos que garantam a correta identificação. Atualmente vêm sendo desenvolvidas duas formas de se contornar este problema: a certificação molecular de colônias pertencentes a laboratórios de referência (chamado de "Código de Barras de DNA") e o desenvolvimento de um método molecular diagnóstico, a PCR Multiplex.

A genotipagem de colônias é uma das melhores soluções para a certificação molecular da identidade das espécies que são doadas para os mais diversos laboratórios mundo afora. $O$ uso de chaves dicotômicas baseadas na morfologia do animal exige experiência e é comum que se identifiquem erroneamente indivíduos pertencentes a complexos de espécies crípticas. Conseqüentemente, muitas colônias formadas por espécimes inadequadamente identificados podem ficar "contaminadas" por indivíduos de outras espécies, podendo levar à geração de animais híbridos. A certificação das colônias é feita através do seqüenciamento de um fragmento do gene mitocondrial cyt $b$ e do segundo espaçador interno ribossomal, o ITS-2, e posterior comparação das sequências geradas com um banco de sequências de espécies pertencentes àquele gênero (é possível obter sequências de diferentes marcadores moleculares para muitas espécies de triatomíneos na base 
de dados do GenBank). Esta certificação já vem sendo feita com as colônias de Rhodnius do Laboratório Nacional e Internacional de Referência em Taxonomia de Triatomíneos do Instituto Oswaldo Cruz, que dispõe de um insetário contendo a maior diversidade de espécies de triatomíneos do mundo (40 ao todo).

Apenas um estudo foi feito até o momento para separar espécies crípticas de triatomíneos com base na metodologia de PCR Multiplex (Pavan \& Monteiro 2007). Neste estudo, foi desenvolvida uma metodologia capaz de separar $R$. prolixus, $R$. robustus I e o grupo $R$. robustus II-IV. Isto é importante, pois $R$. prolixus é morfologicamente indistinguível das quatro espécies de $R$. robustus s.l. E para complicar ainda mais, $R$. prolixus, $R$. robustus I e $R$. robustus IV ocorrem em simpatria em determinadas regiões da Venezuela (Figura 13.10).

O método consiste em poucas etapas metodológicas de baixo custo para se identificar corretamente as espécies. É necessário apenas se extrair o DNA do espécime, fazer uma reação de PCR e analisar o produto em uma eletroforese em gel de agarose. Na PCR, ao invés de se utilizar apenas um par de primers que flanqueiem uma mesma região do gene mitocondrial cyt $b$ das quatro espécies, utilizam-se primers espécie-específicos que amplificam fragmentos de tamanhos distintos ( $R$. robustus II-IV - 239pb; $R$. prolixus - 285pb; e $R$. robustus I - 349pb; Figura 13.11).

\section{Desenvolvimento de um estudo em sistemática molecular de triatomíneos}

Qualquer estudo sobre sistemática molecular de triatomíneos deve começar com a elaboração de uma pergunta bem definida e cientificamente relevante. Em seguida, deve-se pensar em qual desenho experimental (que marcador[es], estratégia amostral e métodos analíticos utilizar) melhor responderá sua pergunta. Além disso, é aconselhável conhecer um pouco sobre a ecologia e distribuição geográfica da espécie a ser estudada para que a busca pelos insetos seja feita 
adequadamente. Onde são encontrados? Nas copas de palmeiras? Em ocos de árvores? Embaixo de pedras? Dentro de casas?

Para isso, é recomendável que se faça um bom levantamento bibliográfico para determinar o que já foi descoberto, o que ainda está por ser e o que é ainda controverso. Abaixo, temos alguns exemplos de perguntas relacionadas à sistemática de triatomíneos e ao controle vetorial. A melhor técnica molecular a utilizar e abrangência geográfica necessária para cada tipo de trabalho são também apresentadas (Tabela 13.2).

Tabela 13.2 - Guia de auxílio para desenho experimental, envolvendo uma pergunta científica relacionada à sistemática molecular de triatomíneos.

\begin{tabular}{|c|c|c|c|c|c|c|}
\hline $\begin{array}{l}\text { Pergunta } \\
\text { científica }\end{array}$ & $\begin{array}{l}\text { Abrangência } \\
\text { geográfica }\end{array}$ & $\begin{array}{c}\text { Locais de } \\
\text { amostragem }\end{array}$ & $\begin{array}{c}\text { Número mínimo } \\
\text { de indivíduos } \\
\text { coletados }\end{array}$ & $\begin{array}{l}\text { Técnica a ser } \\
\text { empregada }\end{array}$ & $\begin{array}{l}\text { Marcador } \\
\text { molecular }\end{array}$ & $\begin{array}{l}\text { Tipo de } \\
\text { análise }\end{array}$ \\
\hline $\begin{array}{l}\text { 1) Será que esta } \\
\text { espécie nominal } \\
\text { representa um } \\
\text { complexo de } \\
\text { espécies } \\
\text { crípticas? }\end{array}$ & Macroescala & $\begin{array}{l}\text { Por toda a } \\
\text { distribuição } \\
\text { geográfica } \\
\text { conhecida } \\
\text { da espécie. }\end{array}$ & $\begin{array}{l}\text { Três indivíduos } \\
\text { por localidade; } \\
30 \text { indivíduos } \\
\text { de cada suposta } \\
\text { espécie. }\end{array}$ & $\begin{array}{l}\text { Sequência } \\
\text { mento de } \\
\text { DNA. }\end{array}$ & $\begin{array}{c}\text { cyt } b \text { (ou COI) } \\
\text { e ITS-2 }\end{array}$ & Filogeográfica \\
\hline $\begin{array}{l}\text { 2) Qual o } \\
\text { grau de } \\
\text { relacionamento } \\
\text { entre as } \\
\text { espécies } \\
\text { estudadas? }\end{array}$ & Macroescala & $\begin{array}{l}\text { Um ou mais } \\
\text { pontos dentro } \\
\text { da distribuição } \\
\text { geográfica } \\
\text { conhecida de } \\
\text { cada espécie }\end{array}$ & $\begin{array}{l}\text { De um a cinco } \\
\text { indivíduos por } \\
\text { localidade } \\
\text { por espécie. } \\
\text { Escolher } \\
\text { criteriosamente } \\
\text { um (ou mais) } \\
\text { outgroups }\end{array}$ & $\begin{array}{l}\text { Sequencia- } \\
\text { mento } \\
\text { de DNA }\end{array}$ & $\begin{array}{c}\text { cyt } b, \text { COI, } 12 S \text {, } \\
16 S \text { e ITS-2 } \\
\text { para especies } \\
\text { mais proxi- } \\
\text { mamante } \\
\text { relacionadas. } \\
18 \text { e } 28 \text { S para } \\
\text { as menos } \\
\text { relacionadas. }\end{array}$ & Filogenética \\
\hline $\begin{array}{l}\text { 3) A qual } \\
\text { espécie } \\
\text { este indivíduo } \\
\text { pertence? }\end{array}$ & - & Pontual & Um & $\begin{array}{l}\text { Sequencia- } \\
\text { mento de } \\
\text { DNA } \\
\text { ou PCR } \\
\text { Multiplex }\end{array}$ & cyt b e ITS-2 & $\begin{array}{l}\text { código de } \\
\text { barras de DNA } \\
\text { / Comparação } \\
\text { do tamanho } \\
\text { das bandas } \\
\text { do multiplex }\end{array}$ \\
\hline $\begin{array}{l}\text { 4) A rein- } \\
\text { festação } \\
\text { das casas é } \\
\text { feita por } \\
\text { populações } \\
\text { silvestres } \\
\text { ou recrudes- } \\
\text { centes? }\end{array}$ & Microescala & $\begin{array}{l}\text { Casas in- } \\
\text { festadas, } \\
\text { peridomicílios } \\
\text { e ambientes } \\
\text { silvestres } \\
\text { próximos } \\
\text { às casas }\end{array}$ & $\begin{array}{c}\text { Trinta indivíduos } \\
\text { por localidade. } \\
\text { Amostrar antes } \\
\text { de aplicar } \\
\text { inseticidas nas } \\
\text { casas e de seis } \\
\text { em seis meses } \\
\text { após a aplicação } \\
\text { por, no míni- } \\
\text { mo, um ano. }\end{array}$ & $\begin{array}{l}\text { Microssa- } \\
\text { télites }\end{array}$ & $\begin{array}{l}\text { Análise de } \\
\text { no mínimo } \\
10 \text { loci }\end{array}$ & Populacional \\
\hline $\begin{array}{l}\text { 5) As popu- } \\
\text { lações } \\
\text { resistentes à } \\
\text { inseticidas } \\
\text { estão } \\
\text { cruzando com } \\
\text { populações não } \\
\text { resistentes? }\end{array}$ & Microescala & $\begin{array}{l}\text { Casa(s) com } \\
\text { populações } \\
\text { resistentes e } \\
\text { casas ad- } \\
\text { jacentes. }\end{array}$ & $\begin{array}{c}\text { Cinquenta } \\
\text { indivíduos por } \\
\text { localidade. } \\
\text { Amostrar de seis } \\
\text { em seis meses por, } \\
\text { no mínimo, } \\
\text { dois anos. }\end{array}$ & $\begin{array}{l}\text { Microssa- } \\
\text { télites }\end{array}$ & $\begin{array}{l}\text { Análise de, } \\
\text { no mínimo, } \\
10 \text { loci }\end{array}$ & Populacional \\
\hline
\end{tabular}

